\title{
Components of health: an analysis in rheumatoid arthritis using quality of life questionnaires and clinical and laboratory variables
}

\author{
Martin Borstlap, Martin van de Laar, John Zant, Jan van der Korst
}

\begin{abstract}
Objective-To gain insight into the overlap between additional information supplied by recently developed health status instruments for rheumatoid arthritis (RA) and traditional clinical and laboratory tests.

Methods-A cross sectional study of 282 outpatients with RA was made. From each patient, variables of clinical and laboratory measurements were obtained and the modified health assessment questionnaire (MHAQ) and a Dutch quality of life questionnaire, the IRGL, were completed. These variables were analysed for their interrelationship.

Results-Clinical and laboratory variables correlated significantly with the scales of the physical dimension and the disease impact scale of the IRGL. Their significant correlations with the IRGL psychological scales were weak. There were no significant correlations between any of the traditional variables and the IRGL social scales. Factor analysis yielded five factors: functionality, pain, depressive mood, social support, and laboratory. The laboratory factor is a measure of the disease process. The other four factors provide a health model.

Conclusion-The results suggest that the IRGL questionnaire that was studied covers a complete health model that incorporates aspects of health that are not measured by clinical and laboratory tests. A simple questionnaire for the psychological and social dimension of health status, however, would probably be more cost effective and easier to use in clinical practice.
\end{abstract}

(Ann Rheum Dis 1993; 52: 650-654)

Institute, Department of Rheumatology, dr Jan van

Breemenstraat 2, 1056 AB Amsterdam The Netherlands M Borstlap M A F J van de Laar J L Zant

$\mathrm{J} \mathrm{K}$ van der Korst

Correspondence to: Dr M A F J van de Laar, Department of

Rheumatology, Medisch Spectrum Twente, PO Box 50000, $7500 \mathrm{KA}$ Enschede, The Netherlands.

Accepted for publication 8 June 1993

Classification, monitoring, and outcome assessments of rheumatic diseases are usually based on clinical measurements and laboratory tests, but these traditional parameters have their drawbacks. ${ }^{1}$ They reflect the physical state of the patient and do not meet the World Health Organisation's definition of health: a state of physical, psychological, and social wellbeing. ${ }^{2}$ In consequence, attention has been drawn to the complex of the non-somatic aspects of disease, often described as quality of life. Several questionnaires have been developed to incorporate this concept. These include generic questionnaires, such as the sickness impact profile and the McMaster health index questionnaire (MHIQ), ${ }^{34}$ and disease-specific questionnaires, such as the arthritis impact measurement scales (AIMS) for rheumatic diseases. ${ }^{5}$ Despite the fact that there is no consensus on the value of these questionnaires in clinical settings they are used in evaluating clinical trials. ${ }^{6-9}$ They have not been used to monitor rheumatoid arthritis (RA) in clinical practice. Kazis et al evaluated the AIMS for clinical practice, but did so in a research setting. ${ }^{10}$ They argue that to meet the demands of clinical practice, quality of life questionnaires should be cost effective, require only limited time for administration, provide easily interpretable scores, and provide information unavailable through conventional testing.

Only a few studies have investigated the relations between quality of life questionnaires and traditional measurements. ${ }^{11-13}$ These have suggested that the former do supply additional information.

The purpose of our study was to compare the informative value of a Dutch quality of life questionnaire, the IRGL (influence of rheumatoid arthritis on health and lifestyle), ${ }^{14}$ with that of the modified health assessment questionnaire (MHAQ) ${ }^{15}$ and several traditional measurements. The IRGL is derived from the AIMS but with modifications in the psychosocial scales. ${ }^{14}$ The IRGL has been validated for Dutch patients with RA. Special attention was given to that information provided by the IRGL but not by the MHAQ, clinical parameters, or laboratory parameters. Such information must be clearly specified and interpreted if it is to be incorporated in a health model or in clinical practice.

Patients and methods
METHODS

The age and sex of the patients were registered. The following clinical data were collected and recorded for all patients: Steinbrocker 
Table 1 Demographic data

\begin{tabular}{|c|c|c|c|}
\hline Variables & Mean & $S D$ & Range \\
\hline Age (years) & $61 \cdot 0$ & $15 \cdot 5$ & $23-90$ \\
\hline Women $(\%)$ & 70 & & \\
\hline Disease duration (years) & $8 \cdot 8$ & $4 \cdot 4$ & $3-25$ \\
\hline Rheumatoid factor positive* (\%) & 51 & & \\
\hline Erosions $^{\star}(\%)$ & 37 & & \\
\hline Rheumatoid nodules* (\%) & 4 & & \\
\hline $\mathrm{ESR} \dagger(\mathrm{mm} / \mathrm{h})$ & 26 & 22 & $0-98$ \\
\hline Ritchie score & $6 \cdot 1$ & $6 \cdot 6$ & $0-41$ \\
\hline Grip strength & 39 & 28 & $0-159$ \\
\hline Steinbrocker $1+2 a \ddagger(\%)$ & 62 & & \\
\hline Steinbrocker $2 b \neq+3+4(\%)$ & 38 & & \\
\hline
\end{tabular}

*At disease onset.

+ESR=erythrocyte sedimentation rate.

$\ddagger$ For definition of classes $2 a$ and $2 b$ see text.

functional class, ${ }^{16}$ in which class 2 was divided into $2 \mathrm{a}$ (minimal restrictions) and $2 \mathrm{~b}$ (patients able to perform usual duties and self care despite moderate restrictions); grip strength, measured by a vigorimeter; $9 \mathrm{~m}$ (30 feet) walking time to the nearest $0 \cdot 1 \mathrm{~s}$; Ritchie score (on a scale from 0 to 78$)^{17}$; Thompson score (on a scale from 0 to 534$)^{18}$; duration of morning stiffness in minutes from arising until maximal improvement with a maximum of 300 minutes; erythrocyte sedimentation rate (ESR; Westergren); and $\mathrm{C}$ reactive protein (CRP; nephelometric) in $\mathrm{mg} / \mathrm{l}$.

Two quality of life questionnaires, the IRGL and the MHAQ were administered. The IRGL comprises a physical, psychological, and social dimension, and a disease impact scale. ${ }^{14}$ The physical dimension consists of 21 items, which yield three scores: mobility on a scale from 7 to 28 , self care on a scale from 8 to 32 , and pain on a scale from 6 to 25 . The psychological dimension consists of 22 items, which yield three scores: anxiety on a scale from 10 to 40 , depression on a scale from 0 to 24 , and cheerfulness on a scale from 0 to 24 . The social dimension consists of 13 items. This dimension is divided by the authors of the IRGL into social network indices and social support scores (potential support (score 5-20), actual support (score 3-12), and mutual visits (score 2-8)) and one rest item. The social network indices are the number of friends and the number of contacts in the neighbourhood; the social support scores are the potential support score on a scale from 5 to 20 , the actual support score on a scale from 3 to 12 , and the mutual visits score on a scale from 2 to 8 . The disease impact scale varies from 10 to 40 . The $M H A Q^{15}$ consists of eight items: dressing, rising from supine position eating, walking, personal hygiene, reach, grip, and social activities. The possible scores range from 0 to 3 for each scale: 0 , without any difficulty; 1 , with some difficulty; 2 , with much difficulty; 3 , impossible. No correction was applied for the use of devices.

\section{STATISTICS}

The statistical analyses were performed with the SPSS V3.1 software package. The descriptive statistics option was first used to determine the distribution characteristics of all variables. A new, normalised variable was introduced for each variable with skewness $\geqslant 1.0$ by taking its natural logarithm. ${ }^{19}$ The strengths of the relations among the variables derived from the IRGL, the MHAQ, and the traditional rheumatological measurements were investigated by Pearson correlation (two sided) matrices. These correlations were not used as an effect measurement. Therefore no correction was applied for the number of tests. The different dimensions composed by these variables were identified by factor analysis followed by varimax rotation. Factor analysis is a statistical technique used to identify a relatively small number of underlying factors that can then be used to represent relations among sets of many variables.

\section{Results}

Of the 397 patients who were invited to participate, 58 refused, 57 were unable to cooperate for various reasons that were not related to their disease, and the remaining 282 were investigated according to the protocol (table 1). There was no significant difference between the three groups in the percentage of patients with positive rheumatoid factor, with joint erosions, or with rheumatoid nodules. Two hundred and sixty eight $(95 \%)$ of the participating patients fulfilled three or more American College of Rheumatology criteria for RA (186 (66\%) fulfilled four or more criteria). ${ }^{20}$ One hundred and ninety seven $(70 \%)$ of the patients were women. At disease onset, $143(51 \%)$ of the participating patients were rheumatoid factor positive, $105(37 \%)$

Table 2 Correlations between 'mutual IRGL $f$ scales'

\begin{tabular}{|c|c|c|c|c|c|c|c|c|c|c|c|c|}
\hline$I R G L$ & Mobility & Self care & Pain & Anxiety & Depression & Cheerfulness & $\begin{array}{l}\text { No of } \\
\text { friends }\end{array}$ & $\begin{array}{l}\text { No of } \\
\text { neighbours }\end{array}$ & $\begin{array}{l}\text { Actual } \\
\text { support }\end{array}$ & $\begin{array}{l}\text { Potential } \\
\text { support }\end{array}$ & $\begin{array}{l}\text { Mutual } \\
\text { visits }\end{array}$ & Impact \\
\hline $\begin{array}{l}\text { Physical } \\
\text { Mobility } \\
\text { Self care } \\
\text { Pain }\end{array}$ & $\begin{array}{c}1 \cdot 00 \\
0 \cdot 64^{\star \star} \\
-0 \cdot 48^{\star \star}\end{array}$ & $\begin{array}{c}0.64^{\star \star} \\
1.00 \\
-0.53^{\star \star}\end{array}$ & $\begin{array}{l}-0.48^{\star \star} \\
-0.53^{\star \star} \\
1.00\end{array}$ & $\begin{array}{l}-0 \cdot 17^{\star} \\
-0 \cdot 25^{\star \star} \\
0 \cdot 32^{\star \star}\end{array}$ & $\begin{array}{r}-0 \cdot 25^{\star \star} \\
-0 \cdot 30^{\star \star} \\
0 \cdot 39^{\star \star}\end{array}$ & $\begin{array}{l}0 \cdot 13 \\
0 \cdot 23^{\star \star} \\
-0 \cdot 25^{\star \star}\end{array}$ & $\begin{array}{r}0.02 \\
0.05 \\
-0.09\end{array}$ & $\begin{array}{r}0.05 \\
0.04 \\
-0.07\end{array}$ & $\begin{array}{r}0.04 \\
0.10 \\
-0.02\end{array}$ & $\begin{array}{r}0.02 \\
-0.09 \\
0.08\end{array}$ & $\begin{array}{r}0.14 \\
0.03 \\
-0.11\end{array}$ & $\begin{array}{r}-0 \cdot 49^{\star \star} \\
-0.49^{\star \star} \\
0.56^{\star \star}\end{array}$ \\
\hline $\begin{array}{l}\text { Psychological } \\
\text { Anxiety } \\
\text { Depression } \\
\text { Cheerfulness }\end{array}$ & $\begin{array}{l}-0 \cdot 17^{\star} \\
-0.25^{\star \star} \\
0 \cdot 13^{2}\end{array}$ & $\begin{array}{r}-0 \cdot 25^{\star \star} \\
-0 \cdot 30^{\star \star} \\
0 \cdot 23^{\star \star}\end{array}$ & $\begin{array}{r}0 \cdot 32^{\star \star} \\
0 \cdot 39^{\star \star} \\
-0 \cdot 25^{\star \star}\end{array}$ & $\begin{array}{c}1 \cdot 00 \\
0.65^{\star \star} \\
-0.52^{\star \star}\end{array}$ & $\begin{array}{l}0.65^{\star \star} \\
1.00 \\
-0.51^{\star \star}\end{array}$ & $\begin{array}{l}-0.52^{\star \star} \\
-0.51^{\star \star} \\
1.00\end{array}$ & $\begin{array}{c}-0 \cdot 22^{\star} \\
-0 \cdot 21^{\star} \\
0 \cdot 29^{\star \star}\end{array}$ & $\begin{array}{r}-0.12 \\
-0.11 \\
0.11\end{array}$ & $\begin{array}{l}0.02 \\
0.04 \\
0.09\end{array}$ & $\begin{array}{r}-0.04 \\
-0.02 \\
0.16\end{array}$ & $\begin{array}{c}-0 \cdot 22^{\star \star} \\
-0 \cdot 18^{\star} \\
0 \cdot 31^{\star \star}\end{array}$ & $\begin{array}{c}0 \cdot 41^{\star \star} \\
0 \cdot 39^{\star \star} \\
-0 \cdot 21^{\star}\end{array}$ \\
\hline $\begin{array}{l}\text { Social } \\
\text { No of friends } \\
\text { No of neighbours } \\
\text { Actual support } \\
\text { Potential support } \\
\text { Mutual visits }\end{array}$ & $\begin{array}{l}0.02 \\
0.05 \\
0 \cdot 04 \\
0.02 \\
0 \cdot 14\end{array}$ & $\begin{array}{r}0.05 \\
0.04 \\
0.10 \\
-0.09 \\
0.03\end{array}$ & $\begin{array}{r}-0.09 \\
-0.07 \\
-0.02 \\
0.08 \\
-0.11\end{array}$ & $\begin{array}{l}-0 \cdot 22^{\star} \\
-0 \cdot 12 \\
0 \cdot 02 \\
-0 \cdot 04 \\
-0 \cdot 22^{\star \star}\end{array}$ & $\begin{array}{l}-0.21^{\star} \\
-0.11 \\
0.04 \\
-0.02 \\
-0.18^{\star}\end{array}$ & $\begin{array}{l}0.299^{\star \star} \\
0.11 \\
0.09 \\
0.16 \\
0.31^{\star \star}\end{array}$ & $\begin{array}{l}1 \cdot 00 \\
0 \cdot 32^{\star \star} \\
0 \cdot 15 \\
0 \cdot 24^{\star \star} \\
0 \cdot 41^{\star \star}\end{array}$ & $\begin{array}{l}0 \cdot 32^{\star \star} \\
1 \cdot 00 \\
0 \cdot 26^{\star \star} \\
0 \cdot 27^{\star \star} \\
0 \cdot 41^{\star \star}\end{array}$ & $\begin{array}{l}0 \cdot 15 \\
0 \cdot 26^{\star \star} \\
1.00 \\
0 \cdot 34^{\star \star} \\
0 \cdot 38^{\star \star}\end{array}$ & $\begin{array}{l}0 \cdot 24^{\star \star} \\
0 \cdot 27^{\star \star} \\
0 \cdot 34^{\star \star} \\
1 \cdot 00 \\
0 \cdot 49^{\star \star}\end{array}$ & $\begin{array}{l}0 \cdot 41^{\star \star} \\
0 \cdot 41^{\star \star} \\
0 \cdot 38^{\star \star} \\
0 \cdot 49^{\star \star} \\
1 \cdot 00\end{array}$ & $\begin{array}{r}-0.08 \\
-0.04 \\
0.09 \\
0.13 \\
-0.08\end{array}$ \\
\hline Impact & $-0.49 \star \star$ & $-0.49 \star \star \star$ & $0.56^{\star \star}$ & $0.41^{\star \star}$ & $0 \cdot 39^{\star \star}$ & $-0 \cdot 21^{\star}$ & -0.08 & -0.04 & 0.09 & $0 \cdot 13$ & -0.08 & 1.00 \\
\hline
\end{tabular}

${ }^{\star} \mathrm{p}<0.01 ;{ }^{\star \star} \mathrm{p}<0.001$. 
Table 3 Correlations between IRGL and MHAQ scales and the variables of clinical and laboratory tests

\begin{tabular}{|c|c|c|c|c|c|c|c|c|c|}
\hline$I R G L$ & $M H A Q$ & Steinbrocker & Grip strength & $\begin{array}{l}9 m \text { (30 feet) } \\
\text { walk time }\end{array}$ & Ritchie & Thompson & Morning stiffness & $E S R$ & $C R P$ \\
\hline \multicolumn{10}{|l|}{ Physical } \\
\hline Mobility & $-0 \cdot 71^{\star \star}$ & $-0.63^{\star \star}$ & $0.53^{\star \star}$ & $-0 \cdot 73^{\star \star}$ & $-0 \cdot 37_{\star \star \star}$ & $-0 \cdot 26^{\star \star}$ & $-0 \cdot 24^{\star \star}$ & $-0 \cdot 46^{\star \star}$ & $-0 \cdot 36^{\star \star}$ \\
\hline Self care & $-0 \cdot 77^{\star \star}$ & $-0 \cdot 60^{\star \star}$ & $0.56^{\star \star}$ & $-0 \cdot 51^{\star \star}$ & $-0 \cdot 41^{\star \star}$ & $-0 \cdot 30^{\star \star}$ & $-0 \cdot 31^{\star \star}$ & $-0 \cdot 31^{\star \star}$ & $-0 \cdot 21^{\star}$ \\
\hline Pain & $0 \cdot 55^{\star \star}$ & $0 \cdot 45^{\star \star}$ & $-0 \cdot 42^{\star \star}$ & $0 \cdot 33^{\star \star}$ & $0 \cdot 54^{\star \star}$ & $0 \cdot 45^{\star \star}$ & $0 \cdot 51^{\star \star}$ & $0 \cdot 30^{\star \star}$ & $0 \cdot 33^{\star \star}$ \\
\hline \multicolumn{10}{|l|}{ Psychological } \\
\hline Anxiety & $0 \cdot 22^{\star}$ & $0 \cdot 20^{\star}$ & $-0 \cdot 10$ & $0 \cdot 16$ & $0 \cdot 21^{\star}$ & $0 \cdot 11$ & $0 \cdot 20^{\star}$ & 0.02 & 0.02 \\
\hline Depression & $0 \cdot 31^{\star \star}$ & $0 \cdot 22^{\star}$ & $-0 \cdot 20^{\star}$ & $0 \cdot 30^{\star \star}$ & $0 \cdot 24^{\star \star}$ & $0 \cdot 14$ & $0 \cdot 21^{\star}$ & $0 \cdot 17^{\star}$ & 0.06 \\
\hline Cheerfulness & $-0 \cdot 25^{\star \star}$ & -0.08 & 0.09 & $-0 \cdot 13$ & $-0 \cdot 12$ & -0.07 & $-0 \cdot 17^{\star}$ & $-0 \cdot 11$ & $-0 \cdot 06$ \\
\hline \multicolumn{10}{|l|}{ Social } \\
\hline No of friends & -0.10 & 0.06 & 0.06 & -0.02 & 0.02 & 0.01 & $-0 \cdot 16$ & $-0 \cdot 10$ & $-0 \cdot 10$ \\
\hline No of neighbours & -0.09 & -0.07 & 0.00 & $-0 \cdot 10$ & 0.02 & -0.01 & -0.03 & -0.03 & -0.08 \\
\hline Actual support & $-0 \cdot 13$ & -0.04 & 0.01 & -0.04 & $0 \cdot 10$ & 0.06 & -0.01 & -0.09 & $-0 \cdot 10$ \\
\hline Potential support & 0.01 & 0.04 & $-0 \cdot 14$ & 0.02 & $0 \cdot 26^{\star \star}$ & $0 \cdot 21^{\star}$ & -0.01 & 0.03 & -0.09 \\
\hline Mutual visits & $-0 \cdot 17^{\star}$ & -0.07 & -0.02 & $-0 \cdot 16$ & 0.04 & 0.04 & $-0 \cdot 12$ & -0.03 & $-0 \cdot 10$ \\
\hline Impact & $0.57^{\star \star}$ & $0.51^{\star \star}$ & $-0 \cdot 37^{\star \star}$ & $0 \cdot 39 \star \star$ & $0.45^{\star \star}$ & $0 \cdot 33^{\star \star}$ & $0 \cdot 35^{\star \star}$ & $0 \cdot 18^{\star}$ & $0 \cdot 20^{\star}$ \\
\hline
\end{tabular}

${ }^{\star} \mathrm{p}<0.01 ;{ }^{\star \star} \mathrm{p}<0.001$.

had joint erosions, and $12(4 \%)$ had rheumatoid nodules. The mean disease duration at the time of the study was $8 \cdot 8$ years.

Five traditional variables, morning stiffness, Ritchie score, Thompson score, walking time, and CRP, and three IRGL scales, depression, number of neighbours, and number of friends, had a skewness to the right greater than $1 \cdot 0$. In their natural logarithms these were reduced to within the accepted margin.

In general, IRGL scales showed strong mutual correlations (table 2). The physical scales correlated significantly, though weakly, with the psychological scales, but not with any of the social scales. Mutual visits and number of friends were related positively to cheerfulness and depression. These were the only correlations between the psychological scales and social scales.

Table 4 Factor analysis: final statistics

\begin{tabular}{llll}
\hline Factor & Eigenvalue & \% of variance & Cumulative \% \\
\hline 1 & 6.49 & 30.9 & 30.9 \\
2 & 2.70 & 12.8 & 43.7 \\
3 & 1.97 & 9.4 & 53.1 \\
4 & 1.41 & 6.8 & 59.9 \\
5 & 1.07 & 5.1 & 65.0 \\
\hline
\end{tabular}

Table 5 Factor analysis after varimax rotation

\begin{tabular}{|c|c|c|c|c|c|}
\hline & Factor 1 & Factor 2 & Factor 3 & Factor 4 & Factor 5 \\
\hline $\begin{array}{l}\text { Steinbrocker } \\
\text { Grip strength } \\
\text { Walking time } \\
\text { MHAQ } \\
\text { IRGL mobility } \\
\text { IRGL self care } \\
\text { IRGL impact }\end{array}$ & $\begin{array}{r}0.77 \\
-0.63 \\
0.81 \\
0.81 \\
-0.84 \\
-0.78 \\
0.55\end{array}$ & & & & \\
\hline $\begin{array}{l}\text { Ritchie } \\
\text { Thompson score } \\
\text { IRGL pain } \\
\text { Morning stiffness }\end{array}$ & & $\begin{array}{l}0 \cdot 84 \\
0 \cdot 84 \\
0 \cdot 59 \\
0 \cdot 61\end{array}$ & & & \\
\hline $\begin{array}{l}\text { IRGL anxiety } \\
\text { IRGL depression } \\
\text { IRGL cheerfulness }\end{array}$ & & & $\begin{array}{r}0 \cdot 83 \\
0 \cdot 81 \\
-0 \cdot 74\end{array}$ & & \\
\hline $\begin{array}{l}\text { IRGL No of friends } \\
\text { IRGL No of neighbours } \\
\text { IRGL actual support } \\
\text { IRGL potential support } \\
\text { IRGL mutual visits }\end{array}$ & & & & $\begin{array}{l}0.49 \\
0.64 \\
0.67 \\
0.71 \\
0.79\end{array}$ & \\
\hline $\begin{array}{l}\text { ESR } \\
\text { CRP }\end{array}$ & & & & & $\begin{array}{l}0 \cdot 80 \\
0 \cdot 77\end{array}$ \\
\hline
\end{tabular}

Loadings between -0.45 and 0.45 are not reflected in this table.
Table 3 shows the correlations of the traditional laboratory and clinical variables with the dimensions of the IRGL. All the traditional variables correlated significantly with the physical dimension of the IRGL. Steinbrocker class, grip strength, and walking time correlated strongly with IRGL mobility and self care, while joint pain, Ritchie score, Thompson score, and morning stiffness had strong correlations with IRGL pain scale. Cheerfulness appeared to be an independent scale and was not associated with any of the traditional variables except morning stiffness, with which it had a weak negative correlation.

The numbers of neighbours and friends did not correlate with any of the clinical or laboratory variables. Mutual visits, walking time, and potential support were weakly associated with the Ritchie score and the Thompson score. The disease impact scale correlated strongly with all traditional variables except the laboratory variables.

Factor analysis yielded five factors with eigenvalues greater than one (table 4 ). The first factor explained $30.9 \%$ of the observed variance; the five factors together, $65 \%$. Varimax rotation was performed to facilitate the interpretation of the results (table 5). The clinical variables together with the physical scales of the IRGL loaded on the first and second factors, which determined almost $44 \%$ of the total variance. The first factor, functionality, was created by the Steinbrocker functional class, grip strength, $9 \mathrm{~m}$ (30 feet) walking time, the MHAQ score, and the IRGL mobility, and self care scales. The Ritchie score, the Thompson score, the IRGL pain scale, and morning stiffness formed the second factor, pain. The third and fourth factors, depressive mood and social support, were defined by psychological and social scales from the IRGL. The fifth factor was determined by the laboratory variables ESR and CRP.

\section{Discussion}

Physical variables are the ones most commonly used for the diagnosis, classification, and monitoring of disease, in the assessment of outcome, and in research. Until recently, the psychosocial impact of chronic diseases, and 
rheumatic diseases in particular, was underestimated.

During the past decade attention has been drawn to the potential use of health status assessment for rheumatoid arthritis. The associated methods have gradually gained acceptance, particularly for evaluating clinical trials. Kazis investigated the use of one total health status questionnaire, the AIMS, in clinical practice, with negative results. ${ }^{10}$

For the study presented here we incorporated an existing quality of life instrument into the clinical assessment of outpatients with RA. We conducted a cross sectional study of the correlations among variables taken from clinical and laboratory data, the MHAQ, and the IRGL, to gain more insight into how and whether the information supplied by these sources overlaps and what information is provided by the IRGL that is not available from other sources. We investigated the correlations among the variables derived from clinical and laboratory tests, the MHAQ, and a quality of life questionnaire in a cross sectional study to gain more insight into the overlap of the information that they provide. The components relevant for a health model were determined by a factor analysis of these variables. In general, the scales from the physical dimension of the IRGL have strong correlations with the clinical and laboratory variables. All of these correlations achieved a significance of $p<0.001$, with the exception of the relation between the CRP and self care, which was less strong $(\mathrm{p}<0 \cdot 01)$. Most of the psychological and social scales showed only weak correlations with the clinical and laboratory variables. An exception is the depression scale, which reached several significant correlations, up to the level of $\mathrm{p}<0.001$, with the traditional variables. The correlations between the IRGL scales and the clinical and laboratory variables that were found in our study are generally higher than those found by Bijlsma et al. ${ }^{12}$ This is probably due to the greater number of patients and the application of a correction for variables with a skew distribution in this study.

Bijlsma et al suggested that the traditional clinical variables are measures of active disease and chronic changes, whereas laboratory variables are measures of the disease process rather than outcome. Our results after factor analysis are consistent with this hypothesis The three factors determined by the physical variables reflect the same aspects: chronic changes by the factor on which Steinbrocker functional class, grip strength, walking time, MHAQ score, and the IRGL mobility and self care scales were loaded; active disease by the factor on which Ritchie score, Thompson score, morning stiffness, and the IRGL pain scale were loaded and both by a laboratory factor on which the CRP and the ESR were loaded. Pincus too found less strong correlations of the MHAQ score with laboratory data and stronger correlations of the MHAQ score with functionality and joint count measures. ${ }^{11}$ The MHAQ score loaded on the first factor, chronic changes, only. This confirms other studies in which the MHAQ was found to have a functional dimension only. ${ }^{11} 21$ The two remaining factors, depressive mood and social support, were composed of IRGL variables only. Consequently, the psychological and social dimensions of quality of life are independent of the physical dimension and traditional variables and do, therefore, supply additional information not available from the more traditional variables.

Our factor analysis provides a five component health model. The components may be labelled: functionality, pain, depression, social interaction, and laboratory. The first four appear to make an independent contribution to health status. The laboratory factor is exceptional in that it is generally judged to be a measure of process rather than outcome and is, as such, of no direct relevance to current health status. ${ }^{1}$ Mason derived an almost similar component model based on a factor analysis of the AIMS, in which functionality was subdivided. ${ }^{22}$ His model consisted of lower extremity function, upper extremity function, affect (resembles depression in our model), symptom (resembles pain), and social interaction.

It is difficult to use health status instruments in clinical practice. The number of questions and the time necessary to fill in the questionnaire and the difficulty of interpreting the data from the questionnaire all provide problems. Kazis studied the use of health status reporting in clinical practice. ${ }^{10}$ Most doctors taking part in that study did feel that health status reports provided some overall clinical help in patient management, primarily in overall patient assessment. The additional information acquired from health status reports, however, did not alter their treatment of patients or their advice to them. They concluded that these reports were of no use for altering patient outcome or for affecting process care. Although both the AIMS and its Dutch variant seem to incorporate all components necessary for a complete health status report, further development will be necessary to obtain a practical instrument for routine clinical use. A reduction in the number of questions would be less time consuming. It is our opinion that establishment of a questionnaire for the evaluation of all the various components of health status in rheumatoid arthritis could benefit patient care. A simple, cost effective questionnaire, however, which examines the psychological and social dimensions of health status not covered by clinical and laboratory tests, will probably be more useful in clinical practice. Such an instrument needs to be developed and clinically tested.

This study was supported by 'het Nationaal Reumafonds (Dutch League against Rheumatism).

1 Fries J F, Spitz P W, Kraines R G et al. Measurement of patient outcome in arthritis. Arthritis Rheum 1980; 23 patient

2 World Health Organization. The first ten years of the World Health Organization. Geneva: WHO, 1958.

3 Bergner M, Bobbitt R A, Carter W B. The sickness impact profile: development and final revision of a health status measure. Med Care 1981; 19: 787-805. 
4 Chambaers L W, MacDonald L A, Tugwell P, Buchanan W W, Kraag G. The McMaster health index questionnaire as a measure of quality of life for patients with rheumatoid arthritis. $\mathcal{F}$ Rheumatol 1982; 9: 780-4.

5 Meenan R F, Gertman P M, Mason J H. Measuring health status in arthritis: the arthritis impact measurement scales. Arthritis Rheum 1980; 23: 146-52.

6 Tugwell P, Bombardier C, Buchanan W W, et al. Methotrexate in rheumatoid arthrits, impact on quality of
life assessed by traditional standard-item and life assessed by traditional standard-item and individualized patient preference health
questionnaires. Arch Intern Med 1990; 150: 59-62.

7 Bombardier C, Ware J, Russell I J, Larson M, Chalmers A Leighton Read J. Auronofin therapy and quality of life in patients with rheumatoid arthritis. $\mathrm{Am} \mathcal{F}$ Med 1986; 81 565-78.

8 Anderson J J, Firschein H E, Meenan R F. Sensitivity of a health status measure to short-term clinical changes in arthritis. Arthritis Rheum 1989; 32: 844-50.

9 van der Heijde D M F M, van Riel P L C M, van de Putte L B A. Sensitivity of a Dutch health assessment questionnaire in trial comparing hydroxychloroquine questionnaire in trial comparing hydroxychloroquine
versus sulphasalazin. Scand $¥$ Rheumatol 1990; 19. versus $407-12$.

10 Kazis L E, Callahan L F, Meenan R F, Pincus T. Health status reports in the care of patients with rheumatoid arthritis. F Clin Epidemiol 1990; 43: 1243-53.

11 Pincus T, Callahan L F, Brooks R H, Fuchs H A, Olsen N J, Kaye J J. Self-report questionnaire scores in rheumatoid arthritis compared with traditional physical, radiographic, and laboratory measures. Ann Intern $\mathrm{Med}$ 1989; 110: 259-66.

12 Bijlsma J W J, Huiskes C J A E, Kraaimaat F W, van der Veen M J, Huber-Bruning O. Relation between patients' own health assessment and clinical and laboratory own health assessment and clinical and laboratory findings
13 Deyo $\mathrm{R} \mathrm{A}$, Inui $\mathrm{T} S$, Leininger $\mathrm{J} \mathrm{D}$, Overman $\mathrm{S} S$ Measuring function outcomes in chronic disease: comparison of traditional scales and a self-administered health status questionnaire in patients with rheumatoid arthritis. Med Care 1983; 21: 180-92.

14 Huiskes C J A E, Kraaimaat F W, Bijlsma J W J. Development of a self-report questionnaire to assess the impact of rheumatic diseases on health and lifestyle. fournal of Rehabilitation Sciences 1990; 3: 65-70.

15 Pincus T, Summey J A, Sorraci S A, Wallston K A Hummon N P. Assessment of patient satisfaction in activities of daily living using a modified Stanford Health Assessment Questionnaire. Arthritis Rheum 1983; 26: 1346-53.

16 Steinbrocker O, Traeger C H, Batterman R C. Therapeutic criteria in rheumatoid arthritis. $\mathscr{f} A M A 1949 ; 140: 659$.

17 Ritchie D M, Boyle J A, McInnes J M, et al. Clinical studies with an articular index for the assessment of joint tenderness in patients with rheumatoid arthritis. $Q \mathcal{F} \mathrm{Med}$ 1968; 37: 393-406.

18 Thompson P W, Silman A J, Kirwan J R, Currey H L F. Articular index of joint inflammation in rheumatoid Articular index of joint inflammation in rheumatoid arthritis: correlation with the

19 de Jonge H, Rumke C L, van Strik R. Medische Statistiek (medical statistics). 1981.

20 Arnett F C, Edworthy S, Block D A, et al. The 1987 revised ARA criteria for rheumatoid arthritis. Arthritis Rheum 1987; 30(suppl 17)

21 Liang $\mathrm{M} \mathrm{H}$. Evaluation of function and health status in rheumatic diseases in clinical research and office practice. Postgraduate Advances in Rheumatology. 1988; III-VIII 1-9.

22 Mason J H, Anderson J J, Meenan R F. A model of health status for rheumatoid arthritis. A factor analysis of the arthritis impact measurement scales. Arthritis Rheum 1988; 31: 14-20. 